\title{
Potential Benefits of Silicon Nutrition to Hydroponically Grown Sweet Basil
}

\author{
Yuan Li and Joseph Heckman \\ Department of Plant Biology, Rutgers University, 59 Dudley Road, New \\ Brunswick, NJ 08901
}

Andrew Wyenandt

Department of Plant Biology, Rutgers University, Rutgers Agricultural Research and Extension Center, 121 Northville Road, Bridgeton, NJ 08302

Neil Mattson
School of Integrative Plant Science, Cornell University, 236 Tower Road,
Ithaca, NY 14853

Edward Durner

Department of Plant Biology, Rutgers University, 59 Dudley Road, New Brunswick, NJ 08901

\section{A.J. Both \\ Department of Environmental Sciences, Rutgers University, 14 College Farm Road, New Brunswick, NJ 08901}

Additional index words. hydroponics, Ocimum basilicum, potassium silicate, temperature

\begin{abstract}
Sweet basil (Ocimum basilicum L.) is a globally cultivated and consumed herb known for its unique aroma and flavor. Sweet basil grows best in warm temperatures, and productivity and marketability decrease when grown under cool conditions $\left(<10^{\circ} \mathrm{C}\right)$. Silicon ( $\mathrm{Si}$ ) is not considered an essential plant nutrient, but it can be beneficial to $\mathrm{Si}$ macroaccumulator plants by alleviating several biotic and abiotic stresses. Recent studies have shown that some microaccumulator species may also benefit from $\mathrm{Si}$. In this study, we examined the effects of different levels $(0,25$, and $75 \mathrm{ppm} \mathrm{Si})$ of $\mathrm{Si}$ amendments on hydroponic basil grown at $23{ }^{\circ} \mathrm{C}$. Si $(75 \mathrm{ppm})$ significantly increased shoot height and weight with no negative impact on plant morphology. All Si-treated basil plants absorbed Si in small quantities and affected the uptake of phosphorus, magnesium, sulfur, iron, manganese, copper, zinc and molybdenum. After an unintentional frost event, basil plants treated with $75 \mathrm{ppm}$ had significantly higher survival rates and reduced cold injury symptoms. We concluded that $\mathrm{Si}$ amendments can have a positive impact on hydroponically grown sweet basil, and that such amendments may reduce plant damage due to occasionally cooler growing temperatures.
\end{abstract}

Sweet basil is a globally important herb crop grown for its unique aroma and flavor

\footnotetext{
Received for publication 17 July 2020. Accepted for publication 1 Sept. 2020.

Published online 5 October 2020.

We gratefully acknowledge Dyna-Gro for providing some of the supplies for this research. We thank the School of Biological and Environmental Sciences for providing a fellowship and research support to Yuan $\mathrm{Li}$ for his $\mathrm{PhD}$ studies at Rutgers University, and the New Jersey Agricultural Experiment Station.

The use of product and trade names in this publication is solely for the purpose of providing scientific information. No endorsement of a particular product is implied. Statements made in this publication do not constitute a specific endorsement of any products over others that may perform similarly.

A.J.B. is the corresponding author. E-mail: both@ sebs.rutgers.edu.

This is an open access article distributed under the CC BY-NC-ND license (https://creativecommons. org/licenses/by-nc-nd/4.0/).
}

(Akbari et al., 2018). Basil is in the mint family (Lamiaceae) and comprises more than 60 species native to tropical regions (Satpute et al., 2019). Field-grown basil is sensitive to cold stress during early spring and fall in temperate regions. Temperatures below $10{ }^{\circ} \mathrm{C}$ lead to significant leaf necrosis and brown discoloration, resulting in significant crop loss due to leaf damage (Ribeiro and Simon, 2007). Cold stress also impacts the essential oil composition, affecting taste, flavor, and marketability (Akbari et al., 2018; Senji and Mandoulakani, 2018). The postharvest shelf life of basil is also negatively impacted by cold temperatures if appropriate temperatures are not maintained during shipping and postharvest handling and can result in significant losses (Cantwell and Reid, 1993).

Datnoff et al. (2007) proposed that plant nutrition could be improved by adding $\mathrm{Si}$ fertilizer. Although $\mathrm{Si}$ is not classified as a plant-essential element, studies have shown that $\mathrm{Si}$ can be beneficial to some crops, including barley, cucumber, melon, pump- kin, rice, soybean, strawberry, sugarcane, and wheat (Datnoff et al., 2001; Liang et al., 2015). The availability of Si usually does not affect plants when grown under optimum conditions. However, when plants are under biotic or abiotic stress, Si can strengthen the plant's defense system, thereby increasing crop productivity (Datnoff, 2014).

The effects of $\mathrm{Si}$ on stress resistance are likely to comprise a combination of changes in plant physiology and the accumulation of $\mathrm{Si}$ in the epidermis (Datnoff et al., 2001). The major effects of $\mathrm{Si}$ deposition include increased rigidity and enhanced protection from insect or fungal penetration (Bakhat et al., 2018; Datnoff et al., 2001; Epstein, 1994, 2009; Liang et al., 2006, 2015). Recent studies have indicated that Si can alter the stress responses at the physiological and molecular levels (Adrees et al., 2015; Debona et al., 2017; Etesami and Jeong, 2018; Gu et al., 2011; Shi et al., 2016). Si has also been shown to be effective against cold stress in some macroaccumulator species (Liu et al., 2009).

Based on their mode of Si uptake (active, passive, exclusive, or combined), plant species can be divided into high-, intermediate-, low-, and nonaccumulators of Si. Si in plants can accumulate to a macronutrient level $(>0.1 \%)$ or micronutrient level $(<0.1 \%)$. Many important food crops are Si microaccumulators, including most leafy greens and basil (Datnoff et al., 2001; Li, 2020; Takahashi et al., 1990). Recent research has shown that under certain stress conditions, some microaccumulators such as potato (Vijaya et al., 2016) and tobacco (Zellner et al., 2011, 2019) can absorb and benefit from Si. Because we suspected that Si may be beneficial to some microaccumulator species, the objective of our study was to evaluate the effects of $\mathrm{Si}$ amendments on sweet basil grown hydroponically at a constant air temperature of $23{ }^{\circ} \mathrm{C}$.

\section{Materials and Methods}

Two greenhouse experiments were conducted to evaluate the effects of Si amendments on hydroponically grown basil. Expt. 1 was initiated on 18 Mar. 2018, and Expt. 2 was initiated on 11 Feb. 2019.

Seedlings used for evaluation were grown as follows. Organic seeds of the basil variety 'Genovese' (Johnny's Selected Seeds, Fairfield, ME) were sown in three sheets of Oasis cubes (Oasis HORTCUBES 1-inch thin-cut growing medium, 276 cells per sheet; Oasis Grower Solutions, Kent, $\mathrm{OH}$ ) with one seed per cell. Sheets were placed in individual seeding trays without bottom drain holes. Trays were placed in a reach-in growth chamber (Environmental Growth Chambers, Chagrin Falls, $\mathrm{OH}$ ) at a constant temperature set point of $20{ }^{\circ} \mathrm{C}, 60 \%$ relative humidity, and photosynthetically active radiation $(P A R)$ intensity of $400 \mu \mathrm{mol} \cdot \mathrm{m}^{-2} \cdot \mathrm{s}^{-1}$ during a $16-\mathrm{h}$ photoperiod. The $P A R$ intensity was delivered by a combination of 10 soft white incandescent lamps (69 W; Philips, 
Table 1. Target nutrient concentrations for the nutrient solution.

\begin{tabular}{|c|c|c|c|c|c|}
\hline Macronutrient & Concn $(\mathrm{mmol} / \mathrm{L})$ & $\mathrm{ppm}^{2}$ & Micronutrient & Concn $(\mu \mathrm{mol} / \mathrm{L})$ & $\mathrm{ppm}$ \\
\hline$\overline{\mathrm{N}}$ & 8.83 & 124 & $\mathrm{Fe}$ & 16.77 & 0.935 \\
\hline K & 5.50 & 215 & B & 1.50 & 0.015 \\
\hline $\mathrm{Ca}$ & 2.06 & 83 & $\mathrm{Cu}$ & 0.38 & 0.025 \\
\hline $\mathrm{S}$ & 1.09 & 35 & Mo & 2.46 & 0.235 \\
\hline
\end{tabular}

${ }^{\mathrm{z}} 1 \mathrm{ppm}=1 \mathrm{mg} \cdot \mathrm{L}^{-1}$.

$\mathrm{N}=$ nitrogen, $\mathrm{P}=$ phosphorus, $\mathrm{K}=$ potassium, $\mathrm{Ca}=$ calcium, $\mathrm{Mg}=$ magnesium, $\mathrm{S}=$ sulfur, $\mathrm{Fe}=$ iron, $\mathrm{Mn}=$ manganese, $\mathrm{B}=$ boron, $\mathrm{Cu}=$ copper, $\mathrm{Zn}=\mathrm{zinc}, \mathrm{Mo}=$ molybdenum.

Table 2. Data acquisition equipment, recording intervals, placement, and calibration methods.

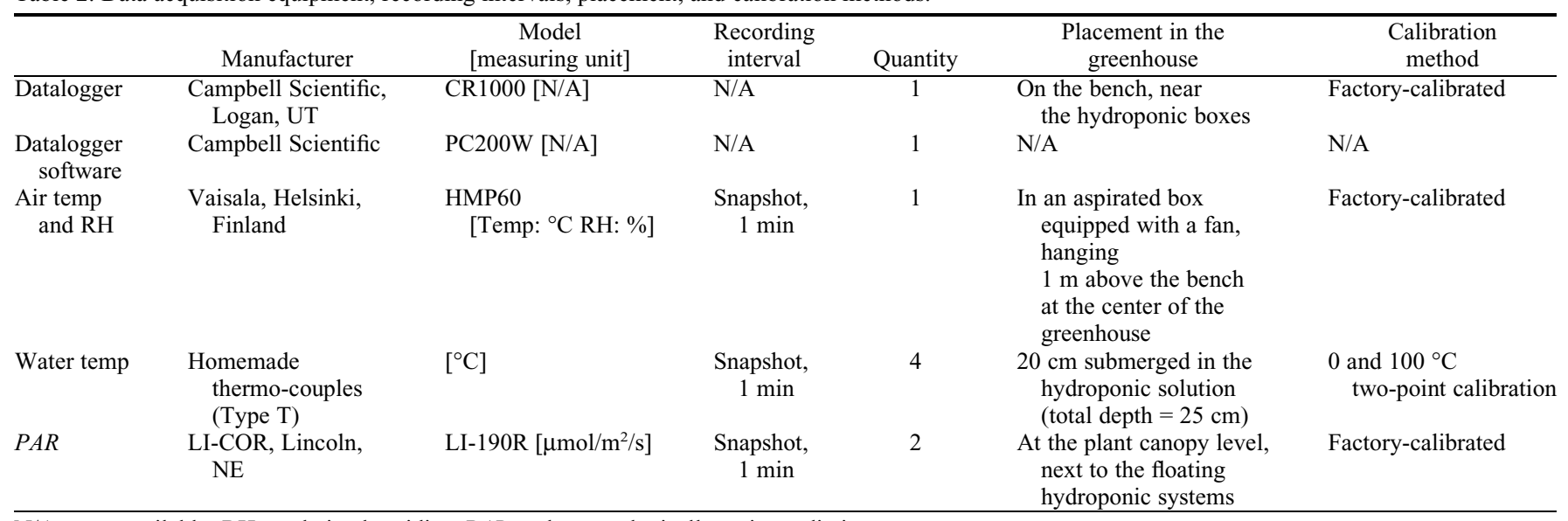

$\mathrm{N} / \mathrm{A}=$ not available; $\mathrm{RH}=$ relative humidity; $P A R=$ photosynthetically active radiation.

Table 3. Calculated averages of greenhouse environmental data after transplanting. Both Expts. 1 and 2 were ended at $30 \mathrm{~d}$ after transplant.

\begin{tabular}{llccccccc}
\hline & & & & & & & & \multicolumn{2}{c}{$\begin{array}{c}\text { RH combined for } \\
\text { day and night }\end{array}$} & DLI \\
\hline Expt. 1 & Avg & 26.5 & 21.5 & 23.1 & 21.4 & 11.8 & 8.2 & 27.3 \\
& SE & 0.74 & 0.15 & 0.48 & 0.16 & 1.15 & 17.9 \\
Expt. 2 & Avg & 25 & 22.3 & 20.5 & 20.7 & 5.9 & 1.05 & 1.53 \\
& SE & 0.37 & 0.1 & 0.34 & 0.32 & 1.07 & 1.19 \\
\hline
\end{tabular}

${ }^{\mathrm{z}}$ Air temperature $\left({ }^{\circ} \mathrm{C}\right)$, hydroponic solution water temperature $\left({ }^{\circ} \mathrm{C}\right)$, outside temperature $\left({ }^{\circ} \mathrm{C}\right)$, greenhouse relative humidity $(\mathrm{RH}, \%)$, and daily light integral $(\mathrm{DLI}$, $\mathrm{mol} / \mathrm{m}^{2} / \mathrm{d}$ ) (day: 6:00 AM-10:00 PM; night: 10:00 PM-6:00 AM).

Table 4. Effects of silicon amendments on plant growth and development for both experiments.

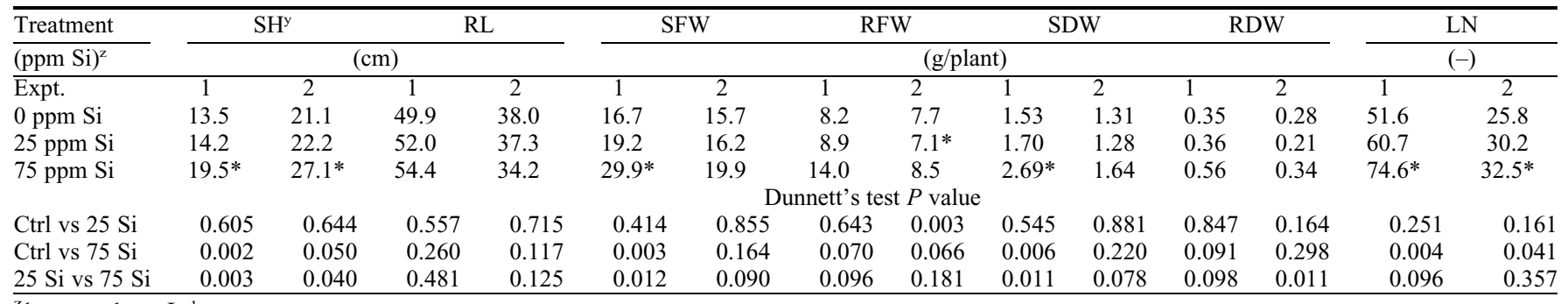

${ }^{\mathrm{z}} 1 \mathrm{ppm}=1 \mathrm{mg} \cdot \mathrm{L}^{-1}$

${ }^{\mathrm{y}}$ Shoot height (SH), root length (RL), shoot fresh weight (SFW), root fresh weight (RFW), shoot dry weight (SDW), root dry weight (RDW), and number of true leaves (LN). Expt. 1: $\mathrm{n}=12$, six plants each from two identical ponds harvested at $30 \mathrm{~d}$ after transplant (DAT) for all treatments. Expt. $2: \mathrm{n}=9$ for the control treatment and $\mathrm{n}=12$ for the $25-\mathrm{ppm}$ and 75 -ppm Si treatments, six plants each from two identical ponds harvested at 30 DAT. Values shown are averages.

*Significantly different from control (Dunnett's test at $P<0.05$ ).

Eindhoven, the Netherlands) and 22 cool white fluorescent lamps (170 W, F72T12CW1500, $4100 \mathrm{~K}$; General Electric, Boston, MA). The resulting spectrum of the lighting system was not evaluated.

After $15 \mathrm{~d}$ in the growth chamber, 128 seedlings of equal sizes were selected from each treatment and transplanted to two replicate 100 -L deep-flow hydroponic systems $(61 \mathrm{~cm}$ long $\times 61 \mathrm{~cm}$ wide $\times 25.4 \mathrm{~cm}$ deep, equivalent to $2 \mathrm{ft} \times 2 \mathrm{ft} \times 10$ inches) supplied with the treatment-specific nutrient solutions and constant aeration using an air pump (GH2716; General Hydroponics, Santa Rosa, CA) with air stones. Each hydroponic system was able to hold $64(8 \times 8)$ plants. The deepflow hydroponic systems were arranged in a double-layer polyethylene-covered greenhouse $(14.6 \mathrm{~m}$ long $\times 7.3 \mathrm{~m}$ wide, equivalent to $48 \mathrm{ft} \times 24 \mathrm{ft}$ ) located at the Rutgers
University Vegetable Research Farm III in New Brunswick, NJ (lat. 40 $27^{\prime} 45^{\prime \prime} \mathrm{N}$, long. $74^{\circ} 25^{\prime} 45^{\prime \prime} \mathrm{W}$; elevation, $21 \mathrm{~m}$ ) and equipped with two ventilation fans $(0.75 \mathrm{HP}, \mathrm{DC} 36$; Windmaster, Muskogee, OK), one natural gas-fired heater with $120,000 \mathrm{BTU} / \mathrm{h}$ output (PDP150AE0130SBAN; Modine Manufacturing Company, Racine, WI), and an integrated temperature control system (ACC-I, Climate Controller Model II; ACME Engineering \& 

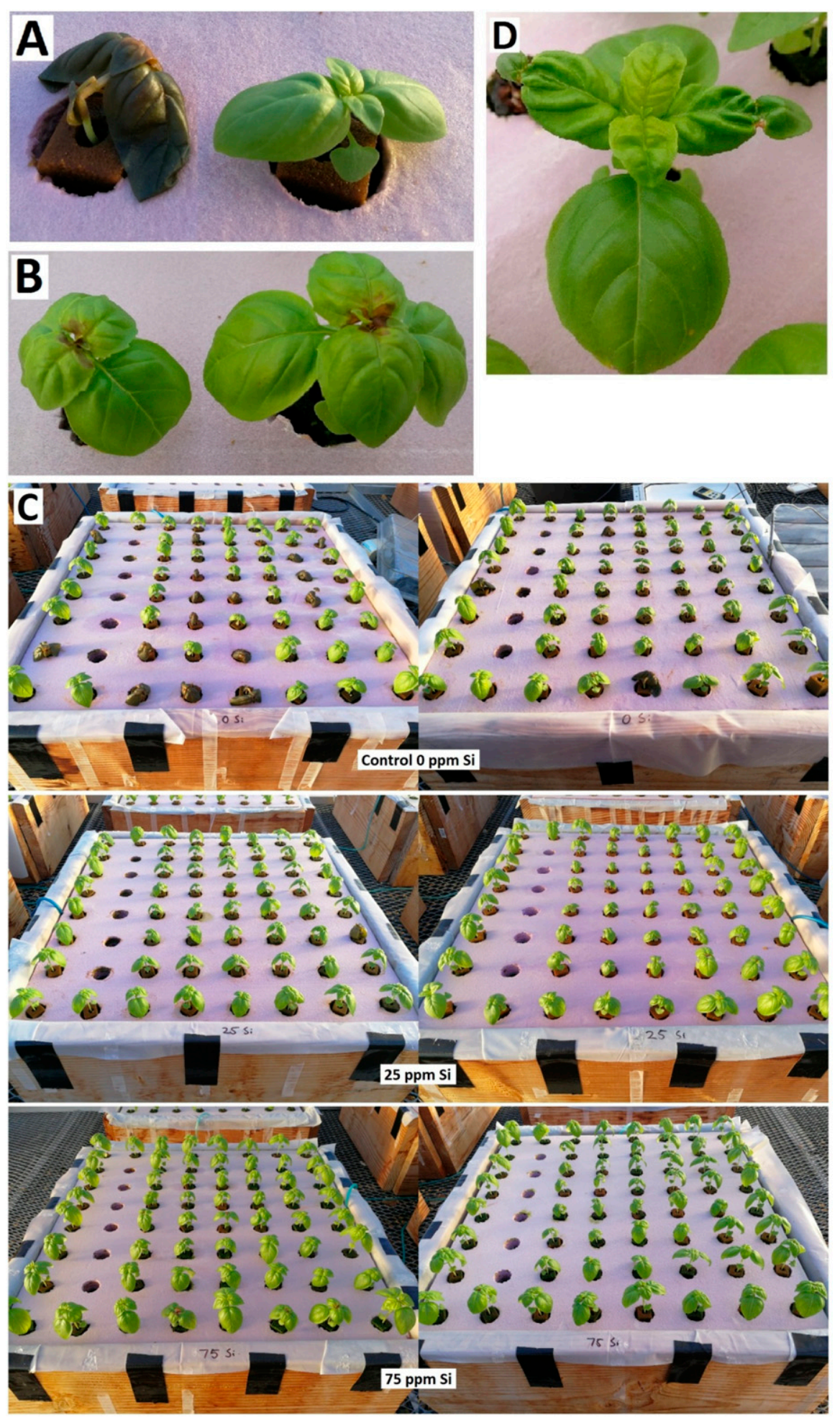

Fig. 1. Plant symptoms caused by an unexpected event involving low air temperature (dropping from $23^{\circ} \mathrm{C}$ to $-1{ }^{\circ} \mathrm{C}$ during a 7-h period at 6 DAT) during Expt. 2. (A) Severe damage symptoms. The entire plant became water-soaked and turned dark green/brown. The photo shows the 0-ppm Si treatment (control). (B) Moderate damage symptoms. Growing tips and newly emerging leaves turned brown. The photo shows the 25-ppm Si treatment. (C) Pictures of the growing boards showing the 0-, 25-, and 75-ppm Si treatments. Si-treated plants mostly survived the low-temperature event, whereas the plants in the control treatment did not fare so well. Images in $\mathbf{A}-\mathbf{C}$ were obtained $6 \mathrm{~h}$ after the low-temperature event. (D) A moderately damaged plant $10 \mathrm{~d}$ after the low-temperature event (16 DAT). The damaged leaves had a twisted and pinched shape, but the morphology of the overall plant and successive newer leaves remained normal. The photo shows a plant from the control treatment. $1 \mathrm{ppm}=1 \mathrm{mg} \cdot \mathrm{L}^{-1}$.

Manufacturing Corporation, Muskogee, $\mathrm{OK})$. Greenhouse air and hydroponic solution temperature, relative humidity, and $P A R$

intensity were recorded once per minute using sensors and a data logger (Table 2). The Si treatments were incorporated in nu- trient solutions using a commercial $\mathrm{K}_{2} \mathrm{SiO}_{3}$ source (Pro-Tekt 0-0-3; Dyna-Gro, Richmond, CA). The solutions were amended with 0 (control), 25 , or $75 \mathrm{ppm}$ of Si for each treatment. The 75-ppm Si treatment was the highest concentration achievable before the formation of a $\mathrm{Ca}_{2} \mathrm{SiO}_{4}$ precipitate. Each seedling tray was irrigated with $2 \mathrm{~L}$ of modified Sonneveld solution (Mattson and Peters, 2014) (Table 1) every other day during the course of each experiment. The system used two stock tanks to reduce precipitation. Tank A contained calcium and iron, and tank B contained phosphorus, magnesium, sulfur, and other micronutrients. The nutrient solutions were all maintained at $\mathrm{pH} 5.8$ using $6 \mathrm{~N}$ nitric acid.

The greenhouse temperature was maintained at $23{ }^{\circ} \mathrm{C}$ during both experiments. The 36 nonguard plants from each hydroponic system were monitored and harvested over six harvests ( $5 \mathrm{~d}$ between each harvest). At each harvest, three plants from each replicate treatment were sampled using a completely random sampling scheme, and each plant was evaluated for root length, shoot and root fresh and dry weight, and the number of true leaves. The shoot heights of the six plants used for the final harvest were measured daily. The experiments were ended $30 \mathrm{~d}$ after transplant (DAT). After measuring the dry weights, plant shoots and roots were separately ground using a tissue grinder (Thomas Scientific, Philadelphia, PA). Tissue analysis for essential elements and $\mathrm{Si}$ in ground shoot and root tissue were performed for the plants collected at the final harvest by ashing the samples (AOAC Official Method 900.02B) (Helrich, 1990) and mixing them in aqua regia before analyses using inductively coupled plasma atomic emission spectroscopy (ICP-AES) at a commercial testing laboratory (MMI Laboratories, Athens, GA). For Expt. 1, all plant shoot or root samples from the same treatment were combined for tissue analysis. For Expt. 2, shoot and root tissues from each individual plant were analyzed, but the laboratory was not able to conduct nitrogen and sulfur analyses of the root samples due to the small sample mass.

All data were analyzed using an analysis of variance (SAS 9.4; SAS Institute, Cary, $\mathrm{NC)}$. All treatments were compared with the control using Dunnett's test at the 0.05 level.

\section{Results and Discussion}

The environmental conditions during both Expts. 1 and 2 are summarized in Table 3 . Both experiments resulted in similar plant growth. At the end of both experiments (30 DAT), the plants treated with $75 \mathrm{ppm} \mathrm{Si} \mathrm{were}$ 43.6\% $(P=0.002$; Expt. 1$)$ and $28.4 \%(P=$ 0.050 ; Expt. 2) taller compared with the control plants. The plants treated with 75 ppm Si had 79\% $(P=0.003)$ higher shoot fresh weight and $75.8 \%(P=0.006)$ higher shoot dry weight in Expt. 1; these values were $26.8 \%(P=0.164)$ and $25.2 \%(P=0.220)$ higher in Expt. 2 (Table 4). The plants treated with $75 \mathrm{ppm}$ Si had 44.6\% $(P=0.004)$ and 
Table 5. Complete tissue analysis of the control, 25-ppm, and 75-ppm Si treatments for basil plants at the final harvest of both Expts. 1 and 2.

\begin{tabular}{|c|c|c|c|c|c|c|c|c|c|c|c|c|c|c|}
\hline & & $\mathrm{Si}$ & $\mathrm{N}^{\mathrm{z}}$ & $\mathrm{P}$ & $\mathrm{K}$ & $\mathrm{Ca}$ & $\mathrm{Mg}$ & $\mathrm{S}$ & $\mathrm{Fe}$ & $\mathrm{Mn}$ & B & $\mathrm{Cu}$ & $\mathrm{Zn}$ & Mo \\
\hline Treatment & Expt. & & & & & $\%$ & & & & & \multicolumn{4}{|c|}{$\mathrm{ppm}^{\mathrm{y}}$} \\
\hline 0 Si shoot & $1^{\mathrm{x}}$ & 0.01 & 3.84 & 0.66 & 4.98 & 2.96 & 0.46 & 0.12 & 78.08 & 176.36 & 32.47 & 9.57 & 517.82 & $\mathrm{~N} / \mathrm{D}^{\mathrm{w}}$ \\
\hline $25 \mathrm{Si}$ shoot & & 0.03 & 4.16 & 0.71 & 3.85 & 3.24 & 0.41 & 0.15 & 84.08 & 196.75 & 32.33 & 8.78 & 532.32 & 0.56 \\
\hline $75 \mathrm{Si}$ shoot & & 0.05 & 4.02 & 0.63 & 4.73 & 2.82 & 0.41 & 0.13 & 64.86 & 89.80 & 31.07 & 5.96 & 394.17 & 0.19 \\
\hline $0 \mathrm{Si}$ root & & 0.02 & 5.24 & 0.93 & 4.81 & 0.41 & 0.83 & 0.18 & 378.98 & 256.93 & 30.79 & 33.72 & 3130.50 & 4.09 \\
\hline $25 \mathrm{Si}$ root & & 0.08 & 5.29 & 1.07 & 5.69 & 0.42 & 0.91 & 0.18 & 447.93 & 263.71 & 36.02 & 30.64 & 3202.40 & 2.46 \\
\hline 75 Si root & & 0.11 & 5.44 & 1.00 & 4.46 & 0.46 & 0.91 & 0.19 & 592.19 & 84.17 & 31.91 & 26.19 & 1487.70 & 2.42 \\
\hline $0 \mathrm{Si}$ shoot & 2 & 0.01 & 4.92 & 0.77 & 5.5 & 2.92 & 0.43 & 0.19 & 85.2 & 85.2 & 28.2 & 6.4 & 422.0 & 1.7 \\
\hline $25 \mathrm{Si}$ shoot & & $0.04 *$ & 5.15 & 0.80 & $6.5^{*}$ & 3.00 & 0.41 & 0.18 & $109.5^{*}$ & 71.1 & 30.0 & 6.5 & 373.3 & 1.9 \\
\hline $75 \mathrm{Si}$ shoot & & $0.06 *$ & 4.76 & $0.68^{*}$ & 6.1 & 2.63 & $0.36^{*}$ & $0.16^{*}$ & 81.9 & $61.7 *$ & 29.2 & $4.4 *$ & $287.2^{*}$ & 1.6 \\
\hline $0 \mathrm{Si}$ root & & 0.04 & $\mathrm{~N} / \mathrm{A}^{\mathrm{v}}$ & 0.94 & 7.1 & 0.50 & 1.36 & N/A & 441.2 & 117.0 & 25.0 & 30.0 & 1359.1 & 6.6 \\
\hline $25 \mathrm{Si}$ root & & $0.09 *$ & N/A & $0.80^{*}$ & 7.7 & 0.48 & $1.11^{*}$ & N/A & 375.6 & $88.0^{*}$ & 24.9 & 26.5 & $899.2^{*}$ & $10.9^{*}$ \\
\hline $75 \mathrm{Si} \mathrm{root}$ & & $0.11^{*}$ & N/A & 0.90 & 6.3 & 0.53 & $1.00 *$ & N/A & 441.8 & $58.4 *$ & 24.5 & 20.0 & $725.9 *$ & $12.6^{*}$ \\
\hline
\end{tabular}

${ }^{\mathrm{z}}$ Tissue harvested at $30 \mathrm{~d}$ after transplant (DAT) were analyzed by inductively coupled plasma atomic emission spectroscopy (ICP-AES) for nitrogen (N), phosphorus $(\mathrm{P})$, potassium $(\mathrm{K})$, calcium $(\mathrm{Ca})$, magnesium $(\mathrm{Mg})$, sulfur $(\mathrm{S})$, iron $(\mathrm{Fe})$, manganese $(\mathrm{Mn})$, boron $(\mathrm{B})$, copper $(\mathrm{Cu})$, zinc $(\mathrm{Zn})$, molybdenum $(\mathrm{Mo})$, and silicon $(\mathrm{Si}) . \mathrm{n}=9$ for the control treatment and $\mathrm{n}=12$ for the 25-ppm and 75-ppm Si treatments, six plants each from two identical ponds harvested at 30 DAT. Values shown are averages.

${ }^{\mathrm{y}} 1 \mathrm{ppm}=1 \mathrm{mg} \cdot \mathrm{L}^{-1}$.

${ }^{\mathrm{x}}$ All plant shoot and root samples from the same treatment were combined for tissue analysis for Expt. 1 . Dunnett's test was not conducted for Expt. 1.

${ }^{\mathrm{w}}$ Nondetectable.

${ }^{\mathrm{v}}$ Nitrogen and sulfur analyses of root samples were not conducted due to the small sample sizes from individual plants, indicated by N/A (not available).

*Significantly different from control (Dunnett's test at $P<0.05$ ).

26\% $(P=0.041)$ more leaves in Expt. 1 and Expt. 2. The differences in root length, root fresh weight, and root dry weight were insignificant (Table 4). At the final harvest, the fully grown roots of individual plants had become tangled with adjacent plants, making careful root separation difficult. The differences in all growth parameters of the control treatment and the plants treated with $25 \mathrm{ppm}$ Si were insignificant for Expt. 1. These differences were considerably larger but still insignificant for Expt. 2 (Table 4). Overall, the high level of Si amendments had a substantial beneficial effect on the growth and yield of basil grown in a cold environment. The effects were more pronounced in the shoots than in the roots.

During Expt. 2, the greenhouse experienced an unexpected power outage for $7 \mathrm{~h}$ during the night at 6 DAT (5 Mar. 2019), and the air temperature inside the greenhouse decreased from 23 to $-1{ }^{\circ} \mathrm{C}$, and the nutrient solution temperature decreased from 21 to $11{ }^{\circ} \mathrm{C}$. At the time, the plants across all treatments had between four and six true leaves. We carefully observed plant responses after this event. Nineteen out of the remaining 116 plants (each treatment started with a total of 128 plants minus 12 plants that were harvested at 5 DAT) from the control treatment showed severe frost damage symptoms. Their shoots appeared water-soaked and turned dark green; then, rot occurred. These plants eventually died and never recovered (Fig. 1A). A single plant treated with $25 \mathrm{ppm}$ Si eventually died because of the low-temperature event, but every plant treated with 75 ppm Si survived (Fig. 1C). Some of the surviving plants showed minor damage on the growing tip and newly emerging leaves, which turned partly brown (Fig. 1B). This minor damage was observed on 42 (out of 97 remaining plants from the control treatment group), 28 (out of 115 remaining plants from the 25-ppm Si treatment group), and 57 (out of
116 remaining plants from the 75-ppm Si treatment group) surviving plants. During the successive growing stages, all surviving plants exhibited normal growth and leaf morphology of the newly developed leaves and the rest of the plant; only one pair of leaves that was damaged during the lowtemperature event exhibited a mildly deformed shape (Fig. 1D).

Although basil is considered a Si microaccumulator, the basil plants absorbed small quantities of $\mathrm{Si}$ in both shoots and roots during both experiments (Table 5). The levels of nitrogen, potassium, and calcium in shoots and roots were not significantly different among the plants in the control, 25, and 75 ppm Si treatment groups, even though more potassium and nitrogen were added to the Siamended plants as a result of the use of $\mathrm{K}_{2}$ $\mathrm{SiO}_{3}$ and nitric acid. Phosphorus levels in the plant shoots of the 75-ppm Si treatment group and roots of the 25-ppm treatment group were significantly higher than those of the control treatment; these results were not consistent with those of previous studies of Si macroaccumulator species grown in soil (Lepolu et al., 2016; Provance-Bowley et al., 2010). As the Si amendment level increased, less magnesium, sulfur, manganese, copper, and zinc were absorbed by the shoots and roots. This was consistent with the results of a previous study of $\mathrm{Si}$ that showed that the uptake of one cation often results in less uptake of other cations (Li et al., 2019). The level of iron was increased in the shoots of plants treated with $25 \mathrm{ppm}$ but not in those treated with $75 \mathrm{ppm}$. The level of molybdenum in the shoots was not significantly different among all treatments, but Si-treated plants had a significant linear increase in the molybdenum content in their roots. Boron levels in the shoots and roots were unaffected by the Si treatments (Table 5).

This is the first report of the effects of $\mathrm{Si}$ nutrition on basil, a $\mathrm{Si}$ microaccumulator crop. To evaluate the beneficial effects of $\mathrm{Si}$ nutrition on economical crops, several studies have focused on various Si macroaccumulators such as citrus (Matichenkov et al., 1999) and orchid (Vendrame et al., 2010). In our study, basil grown under cool conditions, including a cold stress event, benefitted from $\mathrm{Si}$ nutrition without accumulating $\mathrm{Si}$ to a macronutrient level. However, we did not evaluate in detail any structural, physiological, or molecular changes in hydroponic basil plants exposed to elevated levels of Si nutrition. We suspect that the likely mechanism had less involvement in any physical enhancements of the plant tissue resulting from Si deposition; however, we suppose that it is similar to what occurs in other Si microaccumulators such as brassica species (Ashfaque et al., 2017; Pandey et al., 2016) and salvia (Soundararajan et al., 2014). In these species, Si-regulated stress responses occur at the physiological and molecular levels and include changes in the antioxidant system (Adrees et al., 2015; Gu et al., 2011), gas exchange, osmotic adjustments, compatible solute distribution (Debona et al., 2017; Shi et al., 2016), and stress-related phytohormone synthesis (Etesami and Jeong, 2018).

The unexpected cold shock event resulted in a surprising observation that the $\mathrm{Si}$ amendments increased the low temperature tolerance of the basil plants during the early stages of growth. In this unrepeated event, Sitreated basil plants showed reduced injury to cold shock and had higher survival rates compared with the control, and the $75 \mathrm{ppm}$ Si-treated basil plants had significantly higher shoot and number of leaves but not in fresh/dry weight which suggests that further experiments with multiple temperature ranges to evaluate the feasibility of using $\mathrm{Si}$ to alleviate cold stress during the early seedling stage of basil are required. The outcomes of this study will provide greenhouse producers of hydroponic basil with knowledge of 
Si amendments to reduce heating costs during the winter season. In addition, more research is needed to determine how the results described here may be useful during field production, transportation, and postharvest handling of sweet basil. Sweet basil could potentially have extended growing seasons in locations where colder temperatures can be expected.

No formal taste tests were performed at the end of both experiments. Because basil is mostly consumed for its unique taste, olfactory properties, and essential oil composition, we plan to incorporate an analysis of key volatiles and nutritional compounds in our future research.

\section{Literature Cited}

Adrees, M., S. Ali, M. Rizwan, M. Zia-ur-Rehman, and M. Ibrahim. 2015. Mechanisms of siliconmediated alleviation of heavy metal toxicity in plants: A review. Ecotoxicol. Environ. Saf. 119:186-197.

Akbari, G.A., E. Soltani, S. Binesh, and F. Amini. 2018. Cold tolerance, productivity and phytochemical diversity in sweet basil (Ocimum basilicum L.) accessions. Ind. Crops Prod. 124:677-684.

Ashfaque, F., A. Inam, A. Inam, S. Iqbal, and S. Sahay. 2017. Response of silicon on metal accumulation, photosynthetic inhibition and oxidative stress in chromium-induced mustard (Brassica juncea L.). S. Afr. J. Bot. 111:153160.

Bakhat, H.F., N. Bibi, Z. Zia, S. Abbas, H.M Hammad, S. Fahad, M.R. Ashraf, G.M. Shah, F. Rabbani, and S. Saeed. 2018. Silicon mitigates biotic stresses in crop plants: A review. Crop Prot. 104:21-34.

Cantwell, M. and M. Reid. 1993. Postharvest physiology and handling of fresh culinary herbs. J. Herbs Spices Med. Plants 1(3):93125 .

Datnoff, L.E. 2014. Silicon products: Helping plants overcoming biotic and abiotic stresses. NewAG Intl. 2016:32-37.

Datnoff, L.E., G.H. Snyder, and G.H. Korndörfer (eds.). 2001. Silicon in agriculture. 1st ed. Elsevier, Amsterdam, The Netherlands.

Datnoff, L.E., W.H. Elmer, and D.M. Huber (eds.). 2007. Mineral nutrition and plant disease. APS Press, St. Paul, MN.
Debona, D., F.A. Rodrigues, and L.E. Datnoff. 2017. Silicon's role in abiotic and biotic plant stresses. Annu. Rev. Phytopathol. 55:85-107.

Epstein, E. 1994. The anomaly of silicon in plant biology. Proc. Natl. Acad. Sci. USA 91:11-17.

Epstein, E. 2009. Silicon: Its manifold roles in plants. Ann. Appl. Biol. 155:155-160.

Etesami, H. and B.R. Jeong. 2018. Silicon (Si): Review and future prospects on the action mechanisms in alleviating biotic and abiotic stresses in plants. Ecotoxicol. Environ. Saf 147:881-896.

Gu, H., H. Qiu, T. Tian, S.S. Zhan, and T. Deng. 2011. Mitigation effects of silicon rich amendments on heavy metal accumulation in rice (Oryza sativa L.) planted on multi-metal contaminated acidic soil. Chemosphere 83:1234-1240.

Helrich, K. 1990. AOAC: Official methods of analysis (vol. 1). 15th ed. Assn. of Offic. Anal. Chemists, Inc., Arlington, VA.

Lepolu, T.J., J.R. Heckman, J.E. Simon, and C.A Wyenandt. 2016. Silicon soil amendments for suppressing powdery mildew on pumpkin. Sustainability 8:293.

Li, Y., A.J. Both, C.A. Wyenandt, E.F. Durner, and J.R. Heckman. 2019. Applying wollastonite to soil to adjust $\mathrm{pH}$ and suppress powdery mildew on pumpkin. HortTechnology 29:811-820.

Li, Y. 2020. The effects of Silicon nutrition on hydroponically grown lettuce, bok choy and basil. Rutgers Univ., New Brunswick, NJ, PhD Diss. 27-669268.

Liang, M.D., M.C. Gatarayiha, and A. Adandonon. 2006. Silicon use for pest control in agriculture: A review. Proc. S. Afr. Sug. Technol. Ass. 80:278-286.

Liang, Y., M. Nikolic, R. Belanger, H. Gong, and A. Song. 2015. Silicon in agriculture from theory to practice. Springer, Dordrecht, the Netherlands.

Liu, J., S. Lin, P. Xu, X. Wang, and J. Bai. 2009 Effects of exogenous silicon on the activities of antioxidant enzymes and lipid peroxidation in chilling-stressed cucumber leaves. Agr. Sci. China 8(9):1075-1086.

Matichenkov, V., D. Calvert, and G. Snyder. 1999 Silicon fertilizers for citrus in Florida. Proc. Annu. Meet. Fla. State Hort. Soc. 112:5-8.

Mattson, N.S. and C. Peters. 2014. A recipe for hydroponic success. Inside Grower. Ball Publishing, Chicago, IL. 1 May 2019. <http:// www.greenhouse.cornell.edu/crops/factsheets/ hydroponic-recipes.pdf $>$.

Pandey, C., E. Khan, M. Panthri, R. Tripathi, and M. Gupta. 2016. Impact of silicon on Indian mustard (Brassica juncea L.) root traits by regulating growth parameters, cellular antioxidants and stress modulators under arsenic stress. Plant Physiol. Biochem. 104:216-225.

Provance-Bowley, M., J.R. Heckman, and E.F. Durner. 2010. Calcium silicate suppresses powdery mildew and increases yield of field grown wheat. Soil Sci. Soc. Amer. J. 74:16521661

Ribeiro, P. and J.E. Simon. 2007. Breeding sweet basil for chilling tolerance, p. 302-305. In: J. Janick and A. Whipley (eds.). Issues in new crops and new uses. ASHS Press, Alexandria, VA.

Satpute, A., B. Meyering, and U. Albrecht. 2019. Preharvest abscisic acid application to alleviate chilling injury of sweet basil (Ocimum basilicum L.) during cold storage. HortScience 54:155-161

Senji, B.M. and B.A. Mandoulakani. 2018. The impact of cold stress on genes expression pattern of mono- and sesquiterpene biosynthesis and their contents in Ocimum basilicum $\mathrm{L}$. Phytochemistry 156:250-256.

Shi, Y., Y. Zhang, W. Han, R. Feng, and Y. Hu. 2016. Silicon enhances water stress tolerance by improving root hydraulic conductance in Solanum lycopersicum L. Front. Plant Sci $7: 196$

Soundararajan, P., I. Sivanesan, S. Jana, and B. Jeong. 2014. Influence of silicon supplementation on the growth and tolerance to high temperature in Salvia splendens. Hort. Environ. Biotechnol. 55:271-279.

Takahashi, E., J. Ma, and Y. Miyake. 1990. The possibility of silicon as an essential element for higher plants. Comments on Agr. and Food Chem. 2:99-102.

Vendrame, W.A., A.J. Palmateer, A. Pinares, K.A. Moore, and L.E. Datnoff. 2010. Silicon fertilization affects growth of hybrid phalaenopsis orchid liners. HortTechnology 20:603-607.

Vijaya, K., R. Vulavala, R. Elbaum, U. Yermiyahu, E. Fogelman, A. Kumar, and I. Ginzberg. 2016. Silicon fertilization of potato: Expression of putative transporters and tuber skin quality. Planta 243(1):217-229.

Zellner, W., J. Frantz, and S. Leisner. 2011. Silicon delays tobacco ringspot virus systemic symptoms in Nicotiana tabacum. J. Plant Physiol. 168:1866-1869

Zellner, W., L. Lutz, S. Khandekar, and S. Leisner. 2019. Identification of NtNIP2;1: An Lsi1 silicon transporter in N. tabacum. J. Plant Nutr. 42:1028-1035. 